\title{
PEDAGOGY AND METANARRATIVES: EDUCATING IN THE POSTMODERN SITUATION
}

\author{
Jan Hábl
}

\begin{abstract}
This paper deals with historical-philosophical relationship between the so-called metanarratives and pedagogy, as they consider the typical post-modern crisis of trust. The goal of the paper is to outline possible constructive responses to the paradigm change, from a pedagogical point of view.
\end{abstract}

\section{Keywords}

Pedagogy, didactics, metanarratives, modernity/postmodernity, crisis, education, school, paradigm.

\section{INTRODUCTION: METANARRATIVES AND PEDAGOGY}

Much has been spoken and written about the sense of crisis experienced, to a greater or lesser extent, by theoreticians and practitioners of education and training alike. ${ }^{1}$ The school - it is said - "stands at the crossroads", needs to redefine itself, is unable to meet the changing needs and challenges of the times, etc. ${ }^{2}$ I believe that this current sense of crisis is not due to the mismanagement, mistakes or failures of professional educators or educational theory, but to fundamental changes in the paradigm of thought in which the school finds itself with the collapse of the so-called modern metanarratives.

The aim of this brief study is to first outline the roots of the crisis experienced in the modern story of its historical-philosophical context. Then, in light of those roots, to show the way in which the past (not only modern) metanarratives protected their pedagogy as a socio-cultural institution - and what the current decline implies. Finally, I will try to suggest possible ways to constructively address the situation in terms of pedagogy.

Metanarratives in every century have ensured the integrity of human community and the meaningfulness of concretely experienced reality. Every culture has come together around a story that was collectively shared, handed down, and passed on for the purpose of teaching the fundamental orientation and identification of the culture to its members. At the same time, all of the individual

\footnotetext{
1 See for example Haškovec, 2004; Spilková, 2004; Skalková, 1993.

${ }^{2}$ In this study I focus primarily on the area of tertiary education, but whatever is said is also valid for school in general.
} 
components, structures, concepts, values and institutions (including pedagogy) gained their legitimacy precisely in relation to the consensually shared story. And that was the case, not only with the modern story of the autonomous progress of reason, but also with the pre-modern story of transcendentally embodied salvation history. Likewise, older cultures couldn't do without their great stories which gave meaning to all everyday actions. ${ }^{3}$ However the current period, adorned with a host of attributes like 'post-modern', 'reflexively-modern', sur-modern, or late-modern, is different, and new. Among the first to grasp the uniqueness of our time was J. F. Lyotard, when he observed that it's the end of the big story, the ideological whole, and doctrines - that postmodern people don't trust them anymore (comp. 1993). This is what concerns pedagogy and education as such, which finds itself in a historically unprecedented situation because, until now, pedagogy has been inextricably linked with metanarratives. The key question therefore is: What caused the current crisis of confidence in the grand narratives about the meaning of being? And what does it mean for pedagogy?

\section{THE END OF TRUST IN METANARRATIVES}

When the modern story was born the popular Enlightenment philosophers' slogan was: sapere aude (dare to know), which then became "People, trust your own intellect!" It was a reaction against the medieval tradition of trust in external authority. The Enlightenment understood itself as the age of the adolescence of humanity: as that great moment in history when humanity finally gathered the courage to liberate itself from the clutches of ignorance. Thus the newly discovered human ratio became the instrument of emancipation by which humanity hoped "to uncover, describe and explain the entire natural order of things," (Wright, 2004) and it would come about completely autonomously.

In addition to a belief in the nearly omni-potent power of reason, the scenario of the modern story was also based on a belief in the moral progress of humanity. S. Grenz (1997) expressed it well: "The modern scientist considers it as axiomatic, that what knowledge discovers is always good. This assumption of the inherent goodness of knowledge made the enlightened view of the world optimistic. It led to the belief that progress is inevitable, that science, together with the power of education, will finally rid us of both our vulnerability to nature and all social slavery." Encouraged by developments in the field of science, modern humanity began to believe in advancement in the field of morality. After all, the one who knows "rightly" will also act "rightly", (or will

\footnotetext{
${ }^{3}$ This was as true for the oldest semitic cultures as it was for the rest of antiquity. See for example the classic work by Schaeffer, 1980 or Hošek 2010.
} 
he not?). The question of the connection between scientia and conscientia was itself not new, but the assumption that science and education will be the automatically humanizing factor in the process of refining humanity, got its doctrinal form only in the modern story (comp. Menck, 2001). Modern humanity has believed that progress towards a better future is certain and that is only a matter of time; thanks to the unstoppable expansion of knowledge we will be able to control the natural world, even to "command the wind and rain," and ultimately achieve the long sought-after paradise on earth.

In the story of the twentieth century, however, modern hope began to slowly disintegrate. It became apparent that even if knowledge does bring to humanity unprecedented technical capabilities, that alone cannot ensure humaneness and moral refinement. It is clearly true that the one who knows, has power, as F. Bacon has already noted. ${ }^{5}$ Likewise it is indisputable that it is necessary to be led to knowledge, that is, to be taught. Historical experience has revealed, however, that knowledge and education can be used for evil as well as for good. When we think about the atrocities of the twentieth century in which science actively participated, the assumption of the modern period - that science is automatically humanizing - seems ridiculous and even criminally naive. Today, instead of gratefully indulging in the care of scientists, we rather tend to watch them with increasing suspicion and apprehension. Who knows what kind of abuse their techno-scientific creations could be used for again? (comp. Bauman, 2004). The extraordinary development of technology and science, which offers western society unprecedented power and wealth, has also produced a host of problems which have grown to global proportions and no longer can be managed. The culture of abundance and prosperity contrasts sharply with the reality of poverty for millions of starving, destitute, illiterate and marginalized individuals - and even whole nations - which the "civilized" world cannot help because it has enough problems of its own. In E. Fromm's way said, despite the technoscientific saturation humanity is "undernourished." Its advanced technocracy has generated a series of anti-human phenomena like the objectification of mankind, the alienation of individuals, and the depersonalization of interpersonal relationships. Instead of the longed-for paradise on earth, sociologists point out the reality of the dramatic decline of moral literacy, declining social capital (no-one trusts anyone anymore), threats of global self-destruction, clashes of civilizations, various forms of extremism, etc. Human being is even considered to be an "endangered species" (Sokol, 2002).

Another problem of the modern metanarrative that contributed to its decline, was its tendency towards totalitarianism, that is, to act with an exclusive interpretation of reality and the use of power as a tool. M. Foucault described it well

${ }^{4}$ This was a popular slogan of the protagonists of the communist regime who believed it is just a matter of time when science will enable us to control the nature.

${ }^{5}$ The idea that scientia potentia est, Bacon repeated more than once in his period of revolutionary reflections. See for example Bacon's Nové organon (1974), pp. 89, 186. 
when he noted how the modern scientific discourse has been used as a means of all-pervasive dominance and surveillance (2000). The form of monarchist totalitarianism may change, but the essence remains the same. Many a totalitarian atrocity was thus legitimized under the auspices of the grand narratives - whether by the colonialists in the West ${ }^{6}$ or the communists in the East. ${ }^{7}$

The result is that all the simple patterns and reference points on which the modern world was solidly constructed and which facilitated the choosing of life strategies, have been shattered. The next generation, weaned on postmodern milk, no longer perceives reality as a cohesive and coherent whole in which it is possible to find systematic meaning and logic, but rather as a confusion of random and changing events. Truth is an empty concept that means whatever anyone wants it to mean. Objective knowledge is irrelevant. Law and justice have been left at the mercy of the demon of interpretation. And where future prospects are concerned, the post-modern generation does not believe that any scientific, business or economic, let alone political, solution exists that would ensure a better existence than what their parents had. The progress of mankind has been, for the post-modern individual, utterly lost in romantic illusions. Especially in the Eastern Europe setting, where for decades the great truths were bent, twisted and stretched to the utmost, and noble ideas were vulgarized by lower interests, and where one ideological grand narrative after another appeared without ever bringing the promised paradise, it strengthened in almost everyone the conditioned reflex of automatic distrust. We would rather disappoint in advance than ourselves be disappointed again. What are the implications of this change in the intellectual climate for education and the school?

\section{PEDAGOGY WITHOUT METANARRATIVES}

The school has had an irreplacable role within the modern paradigm, as the key means of sharing the meta-stories. All the teaching tools, knowledge, facts, skills and values that it had at its disposal, which it grew, developed and passed on, had their significance directly in the process of implementing the modern

\footnotetext{
${ }^{6}$ In this context A. Finkielkraut nicely captures the link between the concepts of colonization and civilization when he says that to civilize, for the modern westerner means, "to make one's current conditions the example, to make a universal gift of one's own habits, to make one's own values the absolute criteria for assessment, and to consider the European lord and master of nature as the most interesting being in creation. ... Because Europe typified progress to other human societies, colonization seemed to be the fastest and noblest means for bringing the stragglers onto the track of civilization. The calling of industrialized nations seemed to be: to accelerate the path of non-Europeans towards education and welfare. It was necessary, precisely for the good of primitive nations, to swallow up their differences - that is, their backwardness - in Western universality" (1993, p. 42).

${ }^{7}$ The specific consequences of the totalitarian discourse are intimately known by everyone who lived under the communist regime, which also possessed a great story about class struggle and which - many still remember - should have led to the eschatological promise of paradise on earth.
} 
agenda. And the ultimate goal of all educational efforts was said to be to "prepare individuals for life" - which, deconstructed with post-modern hermeneutics, means to mold them to be able to accept and play well their socially determined role in the modern scenario. That it often also included more or less latent indoctrination, follows from the very nature of the story. But the fact remains that it was very functional indoctrination. For centuries it effectively produced and strengthened an almost religious belief in progress. In addition to the overarching metanarratives, the academy belonged to "sacred" things, for it was the key place in which the values of social integration were developed and used. The dignity of the teachers' robes, then, consisted in the inheritance of historical continuity, inasmuch as the modern school, however demarcated it was from the pre-modern school, nevertheless continued in the same tradition. It was that of a persistent and deliberate search for, preservation and transmission of truths which in their diversity were folded into one great unified wholeas indicated in the very notion of uni-versity.

With the end of confidence in the metanarratives the school also came to the end of its most valuable asset. Figuratively speaking, it lost its soul. In losing the great story the school also lost the means by which its formative-educational role in society could be legitimized. The post-modern "client" does not expect great, objective (world)views, definitive statements or binding morals from the school, let alone some kind of educational "machine tooling" in the name of universal truth. All he or she wants is the practical usefulness of the educational products. Do not educate me, just give me the facts, skills and competencies and I will make use of them the way I want. I need to be usable (in the marketplace). ${ }^{8}$

The school has been thus reduced to the position of servant or assistant to the individual's self-determination and self-assertion in the mart-place. In the postmodern climate the school has become the depository, or - not to be pejorative - supermarket, where consumers come to make an eclectic selection from a wide variety of more or less key products which fit his immediate needs. The school has become a place where two worlds of thought meet, mingle and intersect. The school is modern, but its clientele are postmodern. Inasmuch as it is a creation of another period, it appears to the postmodern student as foreign, authoritarian, intolerant, non-user-friendly and even user-hostile. Out of this has come the feeling of crisis in pedagogy.

But that is still not the end of the story. In addition to the loss of its educational-formative legitimacy the modern school has to face a further challenge. A new player has entered the game, one who very willingly took over the space once occupied by the lost metanarratives: mass media. Many sociologists speak

\footnotetext{
${ }^{8}$ The "client" in this context is primarily a college student, but via his/her parents it could also be an elementary school student.

${ }^{9}$ R. Palouš accurately identifies the current state when discussing, for example, "post-education time" (2007).
} 
about the current social order as one of "media-cracy," in which Descartes" "I think, therefore I am" no longer applies, but rather "I am in media, therefore I am.", There have emerged quite different rules of the game. The most valuable commodity of the media is the public's attention. And the immediate harvest of that is popularity. Whoever enters the media game must adhere to its rules, and that by no means favours the intellectual activity which, in the past, brought the school its majesty. Long-term efforts to form character, the cultivation of qualitative values and the careful inspection of truth - all these are activities that the media finds too slow and tedious. They are not really suitable for taking place under the gaze of the public, and thus are unlikely to gain, let alone keep, the public interest. But of course when the media takes over the vacancy left by the metanarratives, educators are forced to compete with celebrities, perverts, terrorists, bank robbers, pandemics, virtual realities and other media products. And they have no chance of winning that game.

With little exaggeration, the current situation of the school stripped of its metanarratives can be compared to a theatre without a play: the scenery has been arranged, the audience is in place, the actors are ready. But there is no play. It is not that the artists have nothing to perform or to say. On the contrary. Drama abounds in a plethora of words, rejoinders, costumes and sets - but there is no plot, no point. Many of the artists try to give their best efforts (despite the amateurish salary in the eastern part of Europe). One lectures with enthusiasm, a second adds nimble somersaults to capture the audience, yet another livens his/her entrance with colorful costumes and still others run around among the spectators in an attempt to draw them into the action. But the bored audience does not respond. It has been supersaturated with incomparably more attractive entertainment. Moreover, without a story the play makes little sense. Somehow, though, they hang on until the end. After all, the admission was free (that will change soon even in Czech Republic).

The school responds to the post-metanarrative situation basically in two ways. The first is to accept the new rules of the game, which in practice means that it conforms to the market criteria. It measures its social usefulness by the market demand for its products. It fights for its own space on the crowded shelves of the market, and its quality is determined only by the success of its sales. What was once perceived as a threat, is now taken by many of the current dignitaries in education as an attractive opportunity. The school - like every other industry - has allowed itself to become a commercial commodity, a profit-making business. Thus has the ability of the school to stand in the competition and satisfy the demands of the market become, once and for all, directly proportional to the influx of money into the education sector. The one who cannot sell, cannot stay in the game.

\footnotetext{
${ }^{10}$ See the classic bestseller by N. Postman Amusing Ourselves to Death.
} 
The second response goes in the opposite direction. Rather than taking the offense, they choose to go on the defense. ${ }^{11}$ To prevent loss in the battle with media the academy retreats to a fortress of social irrelevance. The tall ivory towers, utterly remote from the wider public, offer a safe, self-sufficient, self-nourishing, even "incestuous" - in the words of Z. Bauman - environment for the production and consumption of publicly irrelevant products. The non-marketability of such products is, to be sure, a certain handicap, but relatively bearable inasmuch as it is at least partially offset by grant moonlighting. And the feeling of frustration that many educators experience in the face of post-educational reality, can be effectively compensated for by scientific hyperactivity or the building of pseudo-prestige. ${ }^{12}$

Both strategies, each in their own way, represent a surrendering of the traditional role that the school played in the previous periods. In the first case the school accepts an inferior, service position in the hierarchy that is determined by educationally heterogeneous market forces. In the latter case, the school puts up with cultural and social insignificance, to which it has been condemned by the same unquestioned market principles. The shift from modernity to postmodernity thus represents for education a move from the frying pan to the fire. If the great old stories suffered from a tendency to totalitarian dictates, the new narrative-free story of the market with its media maid do not offer the educator anything better.

\section{CONCLUSION: PEDAGOGY FOR AND AGAINST POSTMODERNITY}

Does there exist yet another path for current education and the school? A more hopeful alternative? I think it does, but it is not easy. The goal of this study is not to present a ready-made educational theory, but rather to suggest the direction, possibility, or starting point for a pedagogy that could adequately respond to the postmodern situation. Whatever the pedagogical approach looks like, I believe that, in order for it to be functional, it will have to include the following features:

a) Repentance. That is, a turning or conversion away from the thinking that understands pedagogy as a practical instrument of power - whether old or new, collectivist or individualistic, market or non-market. The point is to acknowledge the sin of assuming the neutrality of the metanarratives. Both modernism and postmodernism vehemently (and often rightly) condemned the great

\footnotetext{
${ }^{11}$ Perhaps needless to say, this approach usually covers those fields which are inherently difficult to market, such as the humanities.

${ }^{12}$ The epithet "pseudo" is not directed at the quality or professionality of the impact, but rather against publication efforts which are often motivated by market-economic factors - that is, factors which are inauthentic from the perspective of the traditional mission of the school. In other words, the critical question is, "Am I publishing with "impact" because I have prestige, or in order to have prestige?"
} 
doctrines of previous eras, but without reflecting on the framework of their own metanarratives. ${ }^{13}$ Penitential pedagogy will know its doctrines, pre-conceptions and frames of thought - it will openly acknowledge them, examine their authenticity and dialogically reach out to others. Only thus will it be able to avoid the so dreaded indoctrination as an unwanted tool of power.

b) The fortitude to resist the temptation to idolize pseudo-educational substitutes and remain faithful to its original educational calling - this is what will educate, lead and pull humanity out away from everything inhuman. ${ }^{14}$ Educational authoritarianism in various totalitarian forms has been and always will be, dehumanizing; but for education to simply resign itself to it (usually in the name of broad-minded freedom) is not a solution. It would be the equivalent of throwing the baby out with the bath water. Courageous pedagogy will, in the midst of and yet despite the postmodern jungle, look for new, non-dogmatic but responsible paths for education. Paths that is, which can enable a person to prepare for survival in an environment where the criteria for survival is changing faster than survival itself, where there is no coherent system of values, and where the ambivalence and inconsistency of diverse opinions, ideas, frameworks, interests, and truth blend into one great polyphony, or cacophony, which allows an infinite number of interpretations - and where, therefore, it is not possible to predict which expertise or skill will be desirable tomorrow. But courageous pedagogy will go even further. It will not strive merely for survival in this environment, but also for overcoming, exceeding, transcending and reclamation. For if the environment has a anti-educating or corrupting tendency it is precisely responsible education which sets a person back on the path - however much that does not win immediate applause.

c) The last metaphor is faith. Faith which leads to (not only) pedagogically meaningful behaviour. The subject of faith is difficult to grasp and yet is not irrational, because all human behaviour intuitively resists non-sense. Faith does not stand alone, but needs to be applied to instances where it guarantees meaningfulness. And so does pedagogy, as a product of human activity. Exactly contrary to postmodernity which, although it frees humanity from the imposition of totalitarian ideas and beliefs, nevertheless leaves one hungry for an authentic sense of being - pedagogical faith becomes one's greatest asset and competency. This is not simple pedagogical optimism, but an attitude that is humble, honest and constantly looking for a fixed point, fundamental assumption or foundation on which to build a pedagogical house. In narrative terminology, it is a belief that, despite the ruins of postmodern deconstruction, strives to reconstruct the story by which an educator's "narrative" would be made meaningful, effective and hopeful.

\footnotetext{
${ }^{13}$ The postmodern "story" of the disintegration of the meta-stories is itself also a kind of meta-story.

${ }^{14}$ Compare with Palouš's exposition of the notion of "educatio" (1991, p. 63ff).
} 


\section{List of literature and professional sources}

Bacon, F. (1974) Nové organon. Praha: Svoboda.

Bauman, Z. (2004) Individualizovaná společnost. Praha: Mladá fronta.

Finkielkraut, A. (1993) Destrukce myšlení. Brno: Atlantis.

Foucault, M. (2000) Dohližet a trestat.Kniha o zrodu vězení. Praha: Dauphin.

Grenz, S. J. (1997) Úvod do postmodernismu. Praha: Návrat.

Hošek, P. (2010) Proměňující moc příběhu. Církevní dějiny, V.

Haškovec, J. (2004) Současná krize české pedagogiky. Česká pedagogika: Proměny a výzvy, Praha.

Lyoard, J. F. (1993) „Postmoderní situace“. O postmodernismu. Praha: FÚ AV ČR.

Menck, P. (2001) The formation of conscience: a lost topic of Didaktik. Curriculum studies, 2001, vol. 33, III, p. 261-275.

Palouš, R. (1991) Čas výchovy. Praha: Státní pedsgogické nakladatelství.

Palouš, R. (2007) „Doba postedukační?“ Rozhovory, které pokračují. Praha: Eurolex Bohemia.

Postman, N. (2004) Amusing ourselves to death. London: Methuen.

Schaeffer, F. A. (1980) How Should We Then Live? The Rise and Decline of Western Thought and Culture. London: Marshall Morgan \& Scott.

Skalková, J. (1993) Humanizace vzdělávání a výchovy jako soudobý pedagogický problém. Ústí nad Labem: UJEP.

Sokol, J. (2002) Filosofická antropologie. Člověk jako osoba. Praha: Portál, .

Spilková, V. (2004) Pedagogika na Pedagogické fakultě UK - současný stav a perspektivy. Česká pedagogika: Proměny a výzvy, Praha: Karolinum.

Wright, A. (2004) Religion, Education and Postmodernity. London and New York: RoutledgeFalmer.

\section{Contact:}

PhDr. Jan Hábl, Ph.D.

Department of Education

Faculty of Education, J. E. Purkyně University in Ústí nad Labem

Hoření 13

40096 Ústí nad Labem, CZ

E-mail: jan.habl@ujep.cz, Phone: +420 475282168 